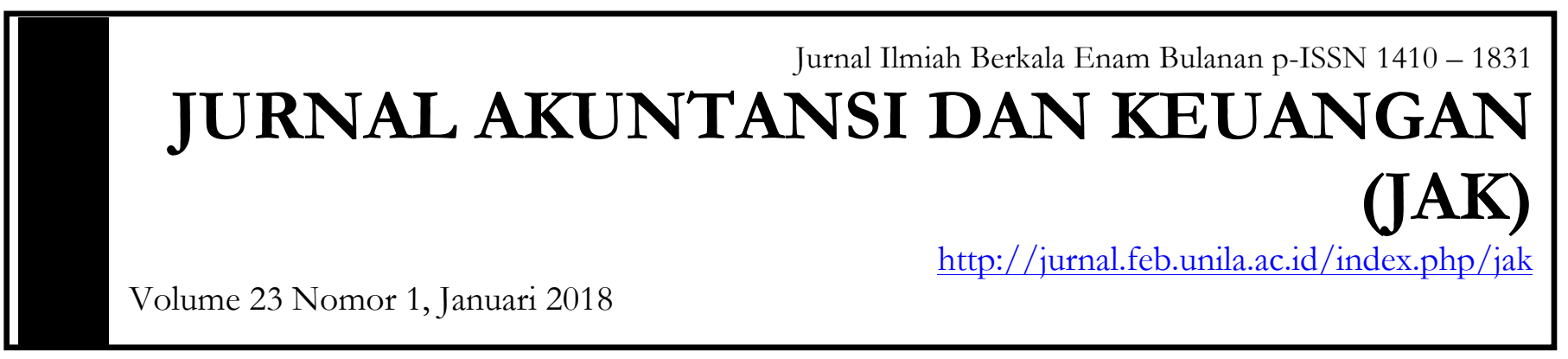

\title{
PENGARUH PROSES REVIU TERHADAP KUALITAS LAPORAN KEUANGAN PEMERINTAH DAERAH
}

Aan Juanda ${ }^{1}$, Pigo Nauli ${ }^{2}$

${ }^{1}$ Program Studi Akuntansi FEB Universitas Lampung

${ }^{2}$ Program Studi Akuntansi FEB Universitas Lampung

\section{Informasi Naskah}

Update Naskah:

Dikumpulkan: 19 Sept

2017;

Diterima: 22 January 2018;

Terbit/Dicetak: 30 January 2019.

\section{Keywords:}

Internal audit, review, goverment accounting standards 


\section{A. PENDAhuluan}

Perkembangan perbankan yang didasarkan pada konsep dan prinsip ekonomi Islam merupakan suatu inovasi dalam sistem perbankan internasional.Keberadaan perbankan syariah dimulai sejak terbitnya undang undang yang menjadi pendorong hadirnya sistem perbankan berbasis syariah yaitu Undang Undang No. 7 Tahun 1992 tentang Perbankan. Dalam perkembangannya, undang-undang tersebut diganti dengan Undang Undang No. 10 Tahun 1998 mengenai sistem perbankan syariah dengan lebih jelas dibandingkan undang-undang sebelumnya. Dengan diberlakukannya undang undang tersebut, perbankan di Indonesia dapat memberlakukan dual banking system atau sistem perbankan ganda, yaitu perbankan konvensional dapat beroperasi secara berdampingan dengan sistem perbankan syariah sebagai suatu unit bank syariah atau unit usaha syariah. Tetapi hal tersebut belum mendorong pertumbuhan perbankan syariah karena masih dipengaruhi oleh sistem perbankan konvensional, sehingga belum terlihat perbedaan yang mencolok mengenai perbankan syariah dan perbankan konvensional.

Sejak diberlakukannya Undang Undang Nomor 21 Tahun 2008 mengenai Perbankan Syariah, sistem perbankan ganda yaitu sistem perbankan konvensional dan sistem perbankan syariah kini semakin kuat pada penerapannya di Indonesia dikarenakan adanya kepastian hukum bagi para nasabah dan menjadikan perbankan syariah sebagai landasan hukum yang jelas dilihat dari sisi kelembagaan dan sistem operasionalnya. Dengan adanya Undang Undang tersebut juga memberikan kenyamanan dalam menggunakan produk produk Perbankan Syariah dan juga dapat memicu peluang yang lebih besar yang diberikan kepada masyarakat untuk mendapatkan pelayanan perbankan yang sesuai dengan sistem syariat Islam.

Dalam ekonomi Islam telah diatur mengenai distribusi hasil usaha (laba bersih) perusahaan kepada pihak-pihak yang terkait.Pendistribusian ini telah diatur oleh hukum-hukum Islam yang berhubungan dengan masalah kepemilikan, perolehan harta, pengelolaan harta, pengembangan harta, mata uang, jual beli dan distribusi kekayaan juga mengenai hak dan kewajiban pihakpihak yang berhubungan dengan perusahaan. Konsep pendistribusian laba diatur dalam syirkah yang mengandung prinsip bahwa pendekatan pendistribusian laba juga mempertimbangkan kemungkinan akan kerugian perusahaan.menurut Ibnu Al-A'rabi dalam Nurhayati (2009) prinsip keadilan akan lebih dapat diciptakan dalam penerapan akuntansi syariah, sesuai dengan salah satu prinsip dasar dalam ekonomi Islam yaitu tidak boleh melakukan transaksi syariah secara tidak adil.

Pada umunya laba dipandang sebagai dasar dalam perhitungan perpajakan, penentuan kebijakan pembayawan deviden, pedoman investasi, pengambilan keputusan, dan unsur prediksi kinerja perusahaan (Belkaoui, 1997).Laba juga dianggap sebagai ukuran efisiensi, dimana laba merupakan ukuran dari kepengurusan manajemen atas pengelolaan sumber daya suatu kesatuan dan ukuran efisiensi manajemen dalam menjalankan usaha perusahaan.Perkembangan konsep laba sendiri terus mengalami perubahan, termasuk juga konsep laba dalam Akuntansi Syariah. Akuntansi Syariah sendiri timbul seiring dengan perkembangan sistem ekonomi islam yang ditandai dengan lahirnya lembaga keuangan syariah, baik yang berbentuk bank maupun non bank. Ada dua konsep Islam yang berkaitan dengan pembahasan konsep laba, yaitu adanya mekanisme pembayaran zakat dan sistem tanpa bunga.

Zakat pada prinsipnya merupakan kesejahteraan agama dan pembayarannya merupakan kewajiban agama.Pelaksanaan pemungutan zakat seharusnya dilakukan oleh pemerintah dan didistribusikan untuk kesejahteraan sosial dengan tujuan untuk beribadah kepada Allah SWT.Zakat dipungut terhadap pendapatan (laba), kepemilikan barang-barang tertentu seperti emas dan perak (atau disetarakan dengan uang), hewan ternak, hasil pertanian, dan juga laba dari kegiatan usaha.Hal ini memerlukan penilaian dan konsep yang jelas untuk menetapkan 
dasar dan besarnya zakat yang harus dibayarkan (Iwan T dan Moch.As'udi, 2001).Keuntungan penggunaan laba sebagai dasar pembayaran zakat adalah dapat mengurangi masalah-masalah yang berkaitan dengan konflik kepentingan dan kecurangan dalam penyajian dan pengungkapan laporan keuangan dapat diminimalisir sebaik mungkin.

Undang Undang no. 39 Tahun 1999 tentang Pengelolaan Zakat yang memperkenankan BAZ/LAZ berkerjasama dengan pihak perbankan dalam penarikan zakat dari para nasabah sangat besar artinya dalam mendorong pengamalan zakat. Beberapa perbankan syariah tercatat telah mendaftarkan LAZ yang mereka dirikan sendiri dan jika dibandingkan dengan BAZ/LAZ lain, pengelolaan zakat oleh perbankan syariah tampaknya lebih unggul dengan adanya ketersediaan sarana dan prasarana pendukung yang memadai, kemampuan manajerial dan administratif pengelola yang relatif lebih baik, dan adanya pelayanan khusus untuk pembiayaan masyarakat ekonomi lemah dalam bentuk pembiayaan al-qard hasan dari dana zakat yang dikelola oleh bank syariah.

Paparan di atas tampak bahwa pengembangan zakat dan perbankan syariah harus berjalan sinergis.Kemajuan pesat industri perbankan syariah saat ini seharusnya dapat menjadi faktor pendorong pengumpulan dan pendistribusian zakat.Hal ini mengingat pertumbuhan perbankan syariah pada hakikatnya merefleksikan menguatnya perekonomian umat sebab berbeda dengan bank konvensional yang dapat terus tumbuh terlepas dari sektor riil, pertumbuhan bank syariah senantiasa sejalan dan tidak bisa dipisahkan dari pertumbuhan di sektor riil.

Dari semua permasalahan tersebut menunjukkan bahwa konsep untuk penentuan dan penilaian laba sangatlah penting dalam akuntansi syariah, baik yang berhubungan dengan operasional perbankan syariah mauan lembaga keuangan syariah lainnya, sekaligus Dalam melakukan urusan pemerintahan, pemerintah daerah mempunyai kewajiban dalam pengelolaan keuangan daerah. Dalam Pasal 280 ayat (2) Undang-undang Nomor 23 Tahun 2014 disebutkan bahwa pemerintah daerah berkewajiban mengelola dana secara efektif, efisien, transparan dan akuntabel. Pertanggungjawaban pelaksanaan pengelolaan keuangan diatur dalam pasal 31 ayat (1) dan (2) Undang-undang Nomor 17 Tahun 2003 tentang Keuangan Negara yang mewajibkan kepala daerah untuk menyampaikan laporan keuangan yang telah diperiksa oleh Badan Pemeriksa Keuangan (BPK) kepada DPRD. Bentuk dan isi laporan keuangan tersebut disusun dan disajikan sesuai dengan standar akuntansi pemerintahan. Komponen Laporan Keuangan Pemerintah Pusat/Daerah setidaknya tidaknya terdiri dari Laporan Realisasi Anggaran, Laporan Perubahan SAL sebagai laporan pelaksanaan anggaran. Neraca, Laporan Operasional, Laporan Perubahan Ekuitas dan Laporan Arus Kas sebagai laporan finansial dan Catatan atas Laporan Keuangan yang merupakan laporan yang merinci atau menjelaskan pos pos laporan pelaksanaan anggaran maupun laporan finansial.

BPK Perwakilan Provinsi Lampung telah melakukan audit atas LKPD tahun 2015. Dari 15 Pemerintah Daerah yang menyampaikan LKPD, masih terdapat 4 Pemerintah Kabupaten yang memperoleh opini WDP dan 14 Kabuapten/Kota sudah memperoleh opini WTP. Secara umum, beberapa faktor yang menyebabkan laporan keuangan pemerintah daerah belum memperoleh opini WTP adalah karena kelemahan dalam penyajian laporan keuangan yang belum sepenuhnya sesuai Standar Akuntansi Pemerintahan (SAP).

Peran APIP sangat diperlukan dalam rangka peningkatan kualitas laporan keuangan pemerintah daerah. Salah satu tugas dan peran APIP yang bersentuhan langsung dengan laporan keuangan pemerintah daerah adalah reviu laporan keuangan. Jika proses reviu ini dilaksanakan dengan baik dan memadai dengan didukung oleh pereviu yang memiliki pemahaman standar akuntansi yang baik maka diharapkan dapat meningkatkan kualitas laporan keuangan pemerintah daerah. Berdasarkan latar belakang sebagaimana diuraikan di atas maka peneliti merumuskan pertanyaan penelitian adalah: (1) Apakah proses reviu laporan keuangan pemerintah daerah yang dilakukan oleh inspektorat berpengaruh terhadap kualitas laporan keuangan pemerintah daerah, (2) Apakah pemahaman standar akuntansi pemerintahan dapat memoderasi pengaruh proses reviu terhadap kualitas laporan keuangan pemerintah daerah 


\section{B. LANDASAN TEORI DAN PENGEMBANGAN HIPOTESIS}

Audit internal adalah aktifitas mandiri/independen yang memberikan jaminan keyakinan serta konsultasi yang didesain untuk memberi nilai tambah dan meningkatkan kegiatan operasional organisasi. Audit internal membantu organisasi dalam upayanya mencapai tujuan dengan memberikan suatu pendekatan disiplin yang sistematis untuk mengevaluasi dan meningkatkan efektifitas resiko manajemen, pengendalian dan proses tata kelola.

Peraturan Menteri Dalam Negeri Nomor 4 Tahun 2008 tentang Pedoman Pelaksanaan Reviu atas Laporan Keuangan Pemerintah Daerah: reviu adalah prosedur penelusuran angka-angka dalam laporan keuangan, permintaan keterangan, dan analitik yang harus menjadi dasar memadai bagi Aparat Pengawasan Intern Pemerintah (APIP) untuk memberi keyakinan terbatas bahwa tidak ada modifikasi material yang harus dilakukan atas laporan keuangan agar laporan keuangan tersebut disajikan berdasarkan Sistem Pengendalian Intern (SPI) yang memadai dan sesuai dengan Standar Akuntansi Pemerintahan (SAP).

Hasil reviu berupa Laporan Hasil Reviu (LHR) yang ditandatangani oleh Inspektur. LHR disajikan dalam bentuk Surat yang memuat Pernyataan Telah Direviu. Pernyataan telah direviu dapat berupa pernyataan dengan paragraf penjelas atau tanpa paragraf penjelas. Reviu atas laporan keuangan dilakukan dalam rangka penyusunan Pernyataan Tanggung Jawab (PTJ) oleh kepala daerah (statement of responsibility) atas laporan keuangan sebelum laporan keuangan tersebut disampaikan kepada BPK. Pernyataan tanggung jawab tersebut menyatakan bahwa laporan keuangan telah disusun berdasarkan sistem pengendalian intern yang memadai dan sesuai dengan standar akuntansi pemerintahan (SAP). Adanya kegiatan reviu terhadap laporan keuangan pemerintah daerah yang dilakukan oleh APIP jika dilaksanakan dengan baik dan memadai akan meningkatkan kualitas laporan keuangan itu sendiri, kemungkinan salah saji dalam laporan keuangan bisa dikurangi dengan adanya kegiatan reviu (Humiang et.al , 2015). Kualitas reviu yang baik bahkan berpengaruh terhadap jumlah temuan BPK. Semakin bagus kualitas reviu yang dilakukan inspektorat maka jumlah temuan BPK akan semakin sedikit (Widarsih, 2015).

\section{Pemahaman Standar Akuntansi Pemerintahan (SAP)}

Satuan kerja perangkat daerah sebagai entitas akuntansi harus dapat menyusun laporan keuangan yang menjadi kewajibanya karena laporan keuangan tersebut dimaksudkan untuk menyediakan informasi yang relevan mengenai posisi keuangan dan seluruh transaksi selama satu periode. Laporan keuangan tersebut disusun dan disajikan sesuai dengan standar akuntansi pemerintahan. Untuk dapat menerapkan SAP dalam penyusunan laporan keuangan yang berkualitas dan sesuai dengan standar akuntansi pemerintahan, maka diperlukan pemahaman yang baik dari pejabat penatausahaan keuangan satuan kerja. Muhaimin dan Yunitarini (2009) menyatakan bahwa pemahaman aparat atas SAP berpengaruh terhadap penerapan SAP dan implementasi sistem akuntansi pemerintahan di pemerintah kabupaten/kota eks Karesidenan Pekalongan.

Standar Akuntansi Pemerintahan (SAP) harus dipahami oleh aparatur pemerintah daerah karena tingkat pemahaman SAP oleh aparatur pemerintah daerah akan berkontribusi menghasilkan Laporan Keuangan Pemerintah Daerah yang berkualitas dan relevan untuk pengambilan keputusan (Setyaningsih, 2013).Auditor pada APIP termasuk dalam rumpun jabatan akuntansi dan anggaran. Auditor harus mempunyai pengetahuan, keterampilan dan kompetensi lainnya yang diperlukan untuk melaksanakan tanggungjawabnya. Kompetensi teknis yang harus dimiliki oleh setiap auditor pada umumnya adalah auditing, akuntansi, administrasi pemerintahan dan komunikasi (BPKP, 2008).

Adanya proses reviu terhadap laporan keuangan pemerintah daerah yang dilakukan oleh APIP yang berkompeten dengan memiliki pemahaman akuntansi pemerintahan yang baik diharapkan dapat meningkatkan kualitas laporan keuangan pemerintah daerah. 


\section{METODE PENELITIAN Desain Penelitian}

Penelitian ini adalah penelitian kuantitatif, yaitu penelitian yang digunakan untuk meneliti pada populasi atau sampel tertentu, pengumpulan data menggunakan instrumen penelitian, analisis data bersifat kuantitatif/statistik dengan tujuan untuk menguji hipotesis yang telah ditetapkan (Sugiyono 2014). Metode penelitian yang digunakan menggunakan metode survey yang dilakukan dengan menggunakan instrumen kuesioner yang terlebih dahulu dijuji validitas dan reabilitasnya, pengumpulan data juga dilakukan dengan observasi.

Populasi dalam penelitian ini adalah seluruh Inspektorat se-Provinsi Lampung. Penelitian ini menggunakan teknik nonprobability sampling yaitu teknik sampling yang tidak memberikan peluang atau kesempatan yang sama bagi setiap unsur anggota populasi. Sample diambil melalui metode purposive sampling dimana responden sengaja dipilih berdasarkan kriteria yang ditetapkan peneliti (Sekaran, 2003). Kriteria yang digunakan dalam penelitian ini adalah APIP yang menjadi anggota tim reviu LKPD.

Responden dalam penelitian ini adalah seluruh pejabat fungsional dan pejabat lainnya yang menjadi anggota tim reviu LKPD pada masing masing inspektorat se-Provinsi Lampung. Responden ini dipilih dalam penelitian ini karena menurut peneliti dapat mewakili masalah yang dirumuskan dalam penelitian.

Penelitian ini adalah penelitian kuantitatif dengan menggunakan data primer yaitu data penelitian yang diperoleh secara langsung dari sumbernya berupa persepsi (opini, sikap, pengalaman) APIP yang menjadi anggota tim reviu LKPD. Penelitian ini juga menggunakan data sekunder dari studi literatur dan Laporan Hasil Pemeriksaan BPK RI atas Laporan Keuangan Pemerintah Daerah.

Untuk mendapatkan data dari responden digunakan instrumen penelitian berupa Kuesioner yang akan diantar sendiri oleh penulis, instrumen dalam kuesioner berisi berbagai pertanyaan/pernyataan yang berkaitan dengan variabel-variabel yang akan diteliti. Kuesioner terbagi menjadi dua bagian yaitu bagian pertama yang berisi data pribadi responden dan bagian kedua berisi pertanyaan dari masing masing operasional variabel. Observasi yang dilakukan berupa pengamatan langsung dan pengambilan data dari anggota tim reviu LKPD.

Penelitian ini menggunakan skala Likert yang digunakan untuk mengukur sikap, pendapat dan persepsi seseorang atau sekelompok orang tentang fenomena sosial.

Tabel 1. Operasional Variabel.

\begin{tabular}{|c|c|c|c|}
\hline Variabel & Dimensi & Indikator & $\begin{array}{c}\text { Kuesioner } \\
\text { No } \\
\end{array}$ \\
\hline $\begin{array}{l}\text { Kualitas LKPD } \\
\text { (Peraturan } \\
\text { Pemerintah } \\
\text { Nomor } 71 \text { Tahun } \\
\text { 2010; Beest, } \\
\text { Braam dan } \\
\text { Boelens (2009) }\end{array}$ & $\begin{array}{l}\text { Andal } \\
\text { Dapat dipahami } \\
\text { Dapat } \\
\text { dibandingkan }\end{array}$ & $\begin{array}{l}\text { 1. manfaat umpan } \\
\text { balik, } \\
\text { 2. manfaat prediktif, } \\
\text { 3. tepat waktu dan } \\
\text { 4. lengkap } \\
\text { 5. Penyajiannya jujur } \\
\text { 6. Dapat } \\
\text { diverifikasi/diuji } \\
\text { 7. Informasi bersifat } \\
\text { netral } \\
\text { 8. Bentuk dan istilah } \\
\text { dapat dipahami }\end{array}$ & $\begin{array}{l}1(\mathrm{~K} 1) \\
2(\mathrm{~K} 2) \\
3(\mathrm{~K} 3) \\
4(\mathrm{~K} 4) \\
5(\mathrm{~K} 5) \\
7(\mathrm{~K} 7) \\
6(\mathrm{~K} 6) \\
8(\mathrm{~K} 8)\end{array}$ \\
\hline
\end{tabular}




\begin{tabular}{|c|c|c|c|}
\hline & & $\begin{array}{l}\text { 9. } \\
\text { Konsistensi } \\
\text { penerapan } \\
\text { kebijakan akuntansi } \\
\text { 10. Perbandingan } \\
\text { internal antar waktu } \\
\text { 11. Perbandingan } \\
\text { eksternal antar } \\
\text { entitas }\end{array}$ & $\begin{array}{l}10(\mathrm{~K} 10) \\
11(\mathrm{~K} 11)\end{array}$ \\
\hline $\begin{array}{l}\text { Pemahaman SAP } \\
\text { Setyaningsih } \\
(2013)\end{array}$ & $\begin{array}{l}\text { Pemahaman umum } \\
\text { SAP } 2010 \\
\text { Pemahaman } \\
\text { struktur SAP } 2010 \\
\text { Mandiri }\end{array}$ & $\begin{array}{l}\text { 1. Tujuan SAP } 2010 \\
\text { 2. Komponen LKPD } \\
\text { 3. Pengakuan unsur } \\
\text { laporan keuangan } \\
\text { 4. Pencatatan dan } \\
\text { penyajian laporan } \\
\text { keuangan }\end{array}$ & $\begin{array}{l}1(\mathrm{P} 1), 3 \\
(\mathrm{P} 1) \\
2(\mathrm{P} 2) \\
6(\mathrm{P} 3), 7 \\
(\mathrm{P} 3) \\
4(\mathrm{P} 4), 5 \\
(\mathrm{P} 4), 8(\mathrm{P} 4) \\
9(\mathrm{P} 5)\end{array}$ \\
\hline $\begin{array}{l}\text { Proses Reviu } \\
\text { Manaf et al. } \\
\text { (2014) }\end{array}$ & $\begin{array}{l}\text { Perencanaan } \\
\text { Pelaksanaan } \\
\text { Pelaporan }\end{array}$ & $\begin{array}{l}\text { 1. Pemahaman entitas } \\
\text { 2. Penilaian SPI } \\
\text { 3. Penyusunan } \\
\text { program kerja } \\
\text { 4. Persiapan } \\
\text { 5. Permintaan } \\
\text { keterangan } \\
\text { 6. Prosedur analitis } \\
\text { 7. Penyusunan } \\
\text { Laporan reviu } \\
\text { 8. Penyampaian } \\
\text { laporan reviu } \\
\end{array}$ & $\begin{array}{l}2(\mathrm{R} 1) \\
4(\mathrm{R} 2), 6 \\
(\mathrm{R} 2) \\
1(\mathrm{R} 3) \\
3(\mathrm{R} 4) \\
5(\mathrm{R} 5) \\
7(\mathrm{R} 6) \\
8(\mathrm{R} 7) \\
9(\mathrm{R} 8)\end{array}$ \\
\hline
\end{tabular}

Analisis model menggunakan Component Based Structural Equation Modeling (SEM) atau Partial Least Square (PLS) dengan menggunakan software SmartPLS Versi 3.2.4. Analisa pada PLS dilakukan dalam 3 tahap yaitu: Analisa Outer Model (Model Pengukuran), Analisa Inner Model (Model Struktural) dan Pengujian Hipotesa.

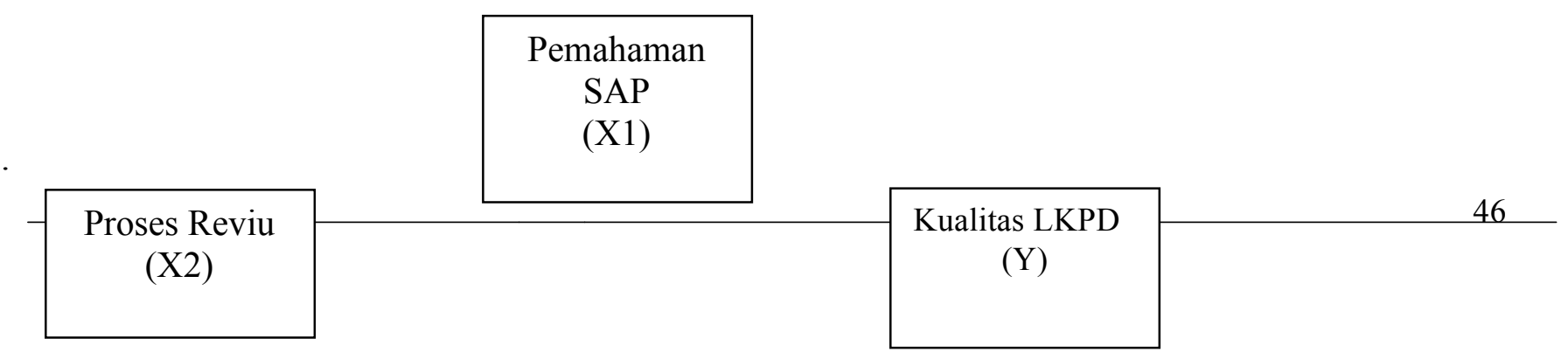




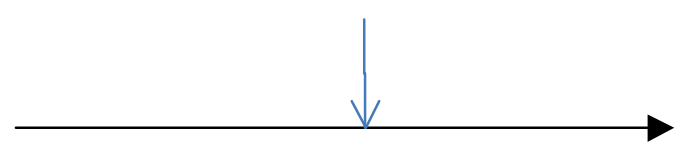

\section{Gambar 2.1 Model Penelitian}

Gambar 2.1. menggambarkan model penelitian yaitu pengaruh variabel Pemahaman SAP (X1) dan Proses Reviu (X2) terhadap Kualitas LKPD (Y)

\section{ANALISIS DAN PEMBAHASAN Hasil Statistik Deskriptif}

\section{Analisis Karakteristik Responden}

Populasi penelitian ini adalah pegawai negeri sipil yang bertugas di inspektorat di seluruh kabupaten/kota se Provinsi Lampung. Ada 15 Inspktorat Kabupate/Kota yang menjadi populasi penelitian. Penelitian ini menggunakan metode purposive sampling dengan kriteria yang digunakan adalah pegawai negeri sipil yang menjadi anggota Tim Reviu LKPD di masing masing inspektorat.

Tabel 2. Hasil deskriptif variabel Pemahaman SAP

E.

\begin{tabular}{|c|c|c|c|c|c|}
\hline $\begin{array}{l}\text { Item } \\
\text { Pemahaman }\end{array}$ & Mean & Median & Min & Max & Modus \\
\hline P1 & 4.223 & 4.000 & 2.000 & 5.000 & 4.000 \\
\hline P2 & 3.734 & 4.000 & 2.000 & 5.000 & 4.000 \\
\hline P3 & 4.353 & 4.000 & 2.000 & 5.000 & 4.000 \\
\hline P4 & 3.625 & 4.000 & 2.000 & 5.000 & 4.000 \\
\hline P5 & 3.647 & 4.000 & 2.000 & 5.000 & 4.000 \\
\hline P6 & 2.658 & 3.000 & 1.000 & 5.000 & 3.000 \\
\hline P7 & 4.033 & 4.000 & 3.000 & 5.000 & 4.000 \\
\hline P8 & 3.886 & 4.000 & 2.000 & 5.000 & 4.000 \\
\hline P9 & 4.277 & 4.000 & 2.000 & 5.000 & 4.000 \\
\hline Rata rata & $3.826 \approx 4$ & $3.889 \approx 4$ & & & 4.000 \\
\hline
\end{tabular}

Tabel 3. Hasil prosentase pilihan responden terhadap variabel Pemahaman SAP

\begin{tabular}{|c|c|c|c|c|c|}
\hline Indikator & $\mathbf{1}$ & $\mathbf{2}$ & $\mathbf{3}$ & $\mathbf{4}$ & $\mathbf{5}$ \\
\hline P1 & $0 \%$ & $2 \%$ & $11 \%$ & $50 \%$ & $37 \%$ \\
\hline P2 & $0 \%$ & $10 \%$ & $22 \%$ & $51 \%$ & $17 \%$ \\
\hline P3 & $0 \%$ & $0 \%$ & $8 \%$ & $48 \%$ & $44 \%$ \\
\hline P4 & $0 \%$ & $10 \%$ & $28 \%$ & $51 \%$ & $11 \%$ \\
\hline P5 & $0 \%$ & $10 \%$ & $28 \%$ & $49 \%$ & $13 \%$ \\
\hline P6 & $8 \%$ & $35 \%$ & $41 \%$ & $15 \%$ & $1 \%$ \\
\hline P7 & $0 \%$ & $0 \%$ & $24 \%$ & $48 \%$ & $28 \%$ \\
\hline P8 & $0 \%$ & $2 \%$ & $24 \%$ & $58 \%$ & $16 \%$ \\
\hline P9 & $0 \%$ & $3 \%$ & $4 \%$ & $54 \%$ & $39 \%$ \\
\hline
\end{tabular}


Tabel 4. Hasil deskriptif variabel Proses Reviu

\begin{tabular}{|c|c|c|c|c|c|}
\hline Item Reviu & Mean & Median & Min & Max & Modus \\
\hline R1 & 4.234 & 4.000 & 2.000 & 5.000 & 4.000 \\
\hline R2 & 3.967 & 4.000 & 2.000 & 5.000 & 4.000 \\
\hline R3 & 4.038 & 4.000 & 2.000 & 5.000 & 4.000 \\
\hline R4 & 4.027 & 4.000 & 2.000 & 5.000 & 4.000 \\
\hline R5 & 4.223 & 4.000 & 3.000 & 5.000 & 4.000 \\
\hline R6 & 3.516 & 4.000 & 1.000 & 5.000 & 4.000 \\
\hline R7 & 4.201 & 4.000 & 2.000 & 5.000 & 4.000 \\
\hline R8 & 4.179 & 4.000 & 2.000 & 5.000 & 4.000 \\
\hline R9 & 4.397 & 4.000 & 3.000 & 5.000 & 4.000 \\
\hline Rata rata & $4.087 \approx 4$ & 4.000 & & & 4.000 \\
\hline \multicolumn{7}{|r}{}
\end{tabular}

F.

Tabel 5. Hasil prosentase pilihan responden terhadap variabel Proses Reviu

\begin{tabular}{|c|c|c|c|c|c|}
\hline Indikator & $\mathbf{1}$ & $\mathbf{2}$ & $\mathbf{3}$ & $\mathbf{4}$ & $\mathbf{5}$ \\
\hline R1 & $0 \%$ & $2 \%$ & $10 \%$ & $51 \%$ & $37 \%$ \\
\hline R2 & $0 \%$ & $3 \%$ & $18 \%$ & $57 \%$ & $22 \%$ \\
\hline R3 & $0 \%$ & $2 \%$ & $16 \%$ & $60 \%$ & $22 \%$ \\
\hline R4 & $0 \%$ & $2 \%$ & $21 \%$ & $49 \%$ & $27 \%$ \\
\hline R5 & $0 \%$ & $0 \%$ & $7 \%$ & $65 \%$ & $28 \%$ \\
\hline R6 & $5 \%$ & $13 \%$ & $21 \%$ & $50 \%$ & $11 \%$ \\
\hline R7 & $0 \%$ & $1 \%$ & $7 \%$ & $63 \%$ & $29 \%$ \\
\hline R8 & $0 \%$ & $1 \%$ & $11 \%$ & $57 \%$ & $31 \%$ \\
\hline R9 & $0 \%$ & $0 \%$ & $5 \%$ & $51 \%$ & $44 \%$ \\
\hline
\end{tabular}

Tabel 6. Hasil deskriptif variabel Kualitas LKPD

G.

\begin{tabular}{|c|c|c|c|c|c|}
\hline $\begin{array}{c}\text { Kualitas } \\
\text { LKPD }\end{array}$ & Mean & Median & Min & Max & Modus \\
\hline Y1 & 4.038 & 4.000 & 2.000 & 5.000 & 4.000 \\
\hline Y2 & 4.245 & 4.000 & 2.000 & 5.000 & 4.000 \\
\hline Y3 & 4.582 & 5.000 & 2.000 & 5.000 & 5.000 \\
\hline Y4 & 4.212 & 4.000 & 3.000 & 5.000 & 4.000 \\
\hline Y5 & 4.293 & 4.000 & 2.000 & 5.000 & 4.000 \\
\hline Y6 & 4.043 & 4.000 & 2.000 & 5.000 & 4.000 \\
\hline Y7 & 4.500 & 5.000 & 2.000 & 5.000 & 5.000 \\
\hline Y8 & 4.223 & 4.000 & 3.000 & 5.000 & 4.000 \\
\hline Y9 & 4.201 & 4.000 & 3.000 & 5.000 & 4.000 \\
\hline Y10 & 4.207 & 4.000 & 2.000 & 5.000 & 4.000 \\
\hline Y11 & 3.946 & 4.000 & 1.000 & 5.000 & 4.000 \\
\hline & $4.266 \approx$ & $4.182 \approx$ & & & 4.000 \\
Rata rata & 4 & 4 & & & \\
\hline
\end{tabular}

Tabel 7. Hasil prosentase pilihan responden terhadap variabel Kualitas LKPD 


\begin{tabular}{|c|c|c|c|c|c|}
\hline Indikator & $\mathbf{1}$ & $\mathbf{2}$ & $\mathbf{3}$ & $\mathbf{4}$ & $\mathbf{5}$ \\
\hline $\mathrm{Y} 1$ & $0 \%$ & $2 \%$ & $15 \%$ & $59 \%$ & $24 \%$ \\
\hline $\mathrm{Y} 2$ & $0 \%$ & $1 \%$ & $14 \%$ & $45 \%$ & $40 \%$ \\
\hline $\mathrm{Y} 3$ & $0 \%$ & $6 \%$ & $3 \%$ & $18 \%$ & $73 \%$ \\
\hline $\mathrm{Y} 4$ & $0 \%$ & $0 \%$ & $15 \%$ & $49 \%$ & $36 \%$ \\
\hline $\mathrm{Y} 5$ & $0 \%$ & $0 \%$ & $5 \%$ & $60 \%$ & $35 \%$ \\
\hline $\mathrm{Y} 6$ & $0 \%$ & $2 \%$ & $13 \%$ & $64 \%$ & $21 \%$ \\
\hline $\mathrm{Y} 7$ & $0 \%$ & $0 \%$ & $1 \%$ & $45 \%$ & $54 \%$ \\
\hline $\mathrm{Y} 8$ & $0 \%$ & $0 \%$ & $10 \%$ & $58 \%$ & $32 \%$ \\
\hline $\mathrm{Y} 9$ & $0 \%$ & $0 \%$ & $12 \%$ & $55 \%$ & $33 \%$ \\
\hline $\mathrm{Y} 10$ & $0 \%$ & $1 \%$ & $13 \%$ & $50 \%$ & $36 \%$ \\
\hline $\mathrm{Y} 11$ & $1 \%$ & $3 \%$ & $22 \%$ & $49 \%$ & $25 \%$ \\
\hline
\end{tabular}

\section{Uji Outer Model}

Pengujian model pengukuran atau outer model dilakukan untuk memastikan bahwa model pengukuran yang digunakan layak untuk dijadikan pengukuran (valid dan reliabel). Validitas model pengukuran dievaluasi dengan Convergent Validity dan Discriminant Validity untuk indikatornya. Convergent Validity dinilai berdasarkan besarnya nilai loading yang menunjukkan korelasi antara item score dengan construct score. Dalam penelitian ini nilai loading $>0,60$ dianggap baik dan layak digunakan dalam penelitian.

Tabel 8. Hasil outer loading variabel Pemahaman SAP sesudah eliminasi

\begin{tabular}{|c|c|c|}
\hline Item & PEMAHAMAN_SAP & Ket \\
\hline P1 & $\mathbf{0 . 7 4 7}$ & Valid \\
\hline P2 & $\mathbf{0 . 8 5 6}$ & Valid \\
\hline P3 & $\mathbf{0 . 7 4 4}$ & Valid \\
\hline P4 & $\mathbf{0 . 8 7 1}$ & Valid \\
\hline P5 & $\mathbf{0 . 7 9 9}$ & Valid \\
\hline P7 & $\mathbf{0 . 8 0 6}$ & Valid \\
\hline P8 & $\mathbf{0 . 7 7 2}$ & Valid \\
\hline
\end{tabular}

Dari tabel 8 dapat dilihat bahwa item P2 memiliki score tertinggi yaitu sebesar 0.856 yang mewakili indikator komponen LKPD, sementara yang terkecil adalah item P3 sebesar 0.744 yang mewakili indikator tujuan SAP.

Setelah item R6 dalam variabel Proses Reviu dikeluarkan dari model, model diestimasi kembali dan didapat faktor loading dari masing masing item yang baru.

Tabel 9. Hasil outer loading variabel Proses Reviu setelah eliminasi

\begin{tabular}{|c|c|}
\hline Item & PROSES REVIU \\
\hline
\end{tabular}




\begin{tabular}{|c|c|c|}
\hline R1 & $\mathbf{0 . 6 6 1}$ & Valid \\
\hline R2 & $\mathbf{0 . 7 5 7}$ & Valid \\
\hline R3 & $\mathbf{0 . 7 4 5}$ & Valid \\
\hline R4 & $\mathbf{0 . 7 7 1}$ & Valid \\
\hline R5 & $\mathbf{0 . 7 2 7}$ & Valid \\
\hline R7 & $\mathbf{0 . 6 5 1}$ & Valid \\
\hline R8 & $\mathbf{0 . 7 6 0}$ & Valid \\
\hline R9 & $\mathbf{0 . 7 2 3}$ & Valid \\
\hline
\end{tabular}

Dari tabel 9 dapat dilihat bahwa item R4 memiliki score tertinggi yaitu sebesar 0.771 yang mewakili indikator penilaian SPI, sementara yang terkecil adalah item R7 sebesar 0.651 yang mewakili indikator prosedur analitis.

Setelah item Y2, Y3 dan Y11 dalam variabel Kualitas LKPD dikeluarkan dari model, model diestimasi kembali dan didapat faktor loading dari masing masing item yang baru.

Tabel 10. Hasil outer loading variabel Kualitas LKPDsetelah eliminasi

\begin{tabular}{|c|c|c|}
\hline Item & $\begin{array}{c}\text { KUALITAS } \\
\text { LKPD }\end{array}$ & Ket \\
\hline Y1 & $\mathbf{0 . 6 6 4}$ & Valid \\
\hline Y10 & $\mathbf{0 . 6 2 4}$ & Valid \\
\hline Y4 & $\mathbf{0 . 7 6 8}$ & Valid \\
\hline Y5 & $\mathbf{0 . 7 4 3}$ & Valid \\
\hline Y6 & $\mathbf{0 . 6 7 7}$ & Valid \\
\hline Y7 & $\mathbf{0 . 6 9 1}$ & Valid \\
\hline Y8 & $\mathbf{0 . 7 1 5}$ & Valid \\
\hline Y9 & $\mathbf{0 . 7 7 2}$ & Valid \\
\hline
\end{tabular}

Dari tabel 10 dapat dilihat bahwa item Y9 memiliki score tertinggi yaitu sebesar 0.772 yang mewakili indikator konsistensi penerapan kebijakan akuntansi, sementara yang terkecil adalah item Y10 sebesar 0.624 yang mewakili indikator perbandingan internal antar waktu.Discriminant Validity dinilai dengan melihat nilai AVE (Average Variance Extracted). Jika nilai AVE > 0,50 maka dikatakan model memiliki nilai Discriminant Validity yang baik.

Tabel 11. AVE (Average Variance Extracted)

\begin{tabular}{|l|c|c|c|}
\hline \multicolumn{1}{|c|}{ Variabel Konstruk } & $\begin{array}{c}\text { Original } \\
\text { Sample }\end{array}$ & T Statistics & P Values \\
\hline KUALITAS LKPD_ & $\mathbf{0 . 5 0 2}$ & 15.082 & 0.000 \\
\hline Moderating Effect & $\mathbf{1 . 0 0 0}$ & & \\
\hline PEMAHAMAN_SAP & $\mathbf{0 . 6 4 1}$ & 26.091 & 0.000 \\
\hline PROSES_REVIU & $\mathbf{0 . 5 2 7}$ & 18.773 & 0.000 \\
\hline
\end{tabular}

Dari tabel 11 di atas dapat dilihat semua variabel konstruk memiliki nilai AVE $>0,50$. Jadi semua konstruk dalam model memenuhi kriteria discriminant validity.

Disamping uji validitas dilakukan juga uji reabilitas. Reabilitas diukur dengan dua kriteria yaitu 
Composite Reliability dan Cronbach's Alpha. Konstruk dikatakan reliabel jika nilai keduanya >0,70.

Tabel 12. Composite Reliability

\begin{tabular}{|l|c|c|c|}
\hline \multicolumn{1}{|c|}{ Variabel konstruk } & $\begin{array}{c}\text { Original } \\
\text { Sample }\end{array}$ & T Statistics & P Values \\
\hline KUALITAS LKPD & $\mathbf{0 . 8 8 9}$ & 64.937 & 0.000 \\
\hline Moderating Effect & $\mathbf{1 . 0 0 0}$ & & \\
\hline PEMAHAMAN_SAP & $\mathbf{0 . 9 2 6}$ & 122.930 & 0.000 \\
\hline PROSES_REVIU & $\mathbf{0 . 8 9 9}$ & 84.778 & 0.000 \\
\hline
\end{tabular}

Tabel 13. Cronbach's Alpha

\begin{tabular}{|l|c|c|c|}
\hline \multicolumn{1}{|c|}{ Variabel konstruk } & $\begin{array}{c}\text { Original } \\
\text { Sample }\end{array}$ & T Statistics & P Values \\
\hline KUALITAS LKPD_ & $\mathbf{0 . 8 6 0}$ & 48.708 & 0.000 \\
\hline Moderating Effect & $\mathbf{1 . 0 0 0}$ & & \\
\hline PEMAHAMAN_SAP & $\mathbf{0 . 9 0 6}$ & 89.950 & 0.000 \\
\hline PROSES_REVIU & $\mathbf{0 . 8 7 2}$ & 58.671 & 0.000 \\
\hline
\end{tabular}

Dari kedua tabel 12 dan tabel 13 di atas dapat dilihat semua variabel konstruk meiliki nilai Composite Reliability dan Cronbach's Alpha $>0,70$. Sehingga dapat disimpulkan model memiliki reliabilitas yang baik.

\section{Uji Inner Model}

Model struktural atau inner model menggambarkan hubungan antara variabel laten. Model struktural dievaluasi dengan menggunakan koefisien determinasi atau $\mathrm{R}^{2}$ untuk konstruk dependen dan Predictive Relevance dengan Stone-Geisser-Q-Square atau $\mathrm{Q}^{2}$ dan koefisien jalur.

Tabel 14. $\mathbf{R}^{2}$

\begin{tabular}{|l|c|c|c|}
\hline & $\begin{array}{c}\text { Original } \\
\text { Sample }\end{array}$ & T Statistics & $\begin{array}{c}\text { P } \\
\text { Values }\end{array}$ \\
\hline $\begin{array}{l}\text { KUALITAS } \\
\text { LKPD_ }\end{array}$ & 0.351 & 6.517 & 0.000 \\
\hline
\end{tabular}

Dari tabel 14 di atas dapat dilihat bahwa variabel Kualitas LKPD dapat dijelaskan oleh variabel Pemahaman SAP dan variabel Proses Reviu sebesar 35\% sedangkan 65\% dijelaskan oleh variabel lain diluar penelitian ini. Nilai $\mathrm{R}^{2}$ sebesar 0.35 menurut Chin (1998) termasuk dalam kategori moderat.

Sementara $\mathrm{Q}^{2}$ mengukur seberapa baik nilai observasi dihasilkan oleh model dan juga estimasi parameternya. Nilai $\mathrm{Q}^{2}>0$ menunjukkan bahwa model memiliki predictive relevance.

Tabel 15. $Q^{2}$

\begin{tabular}{|l|c|}
\hline & $\mathbf{Q}^{\mathbf{2}}$ \\
\hline $\begin{array}{l}\text { KUALITAS } \\
\text { LKPD_ }\end{array}$ & 0.146 \\
\hline
\end{tabular}


Dari tabel 15 di atas dapat dilihat bahwa nilai $Q^{2}$ sebesar 0,146 > 0 yang menunjukkan bahwa model memiliki predictive relevance. Dari hasil analisis statistik dengan menggunakan SmartPLS Versi 3.2.4, diperoleh hasil Path Coefficients sebagaimana disajikan tabel dibawah ini.

Tabel 16. Hasil estimasi path coefficients

\begin{tabular}{|l|c|c|c|}
\hline & $\begin{array}{c}\text { Original } \\
\text { Sample }\end{array}$ & T Statistics & P Values \\
\hline $\begin{array}{l}\text { Moderating -> KUALITAS } \\
\text { LKPD_ }\end{array}$ & 0.199 & 3.246 & 0.001 \\
\hline $\begin{array}{l}\text { PROSES_REVIU -> } \\
\text { KUALITAS LKPD_ }\end{array}$ & 0.303 & 4.185 & 0.000 \\
\hline $\begin{array}{l}\text { PEMAHAMAN_SAP -> } \\
\text { KUALITAS LKPD_ }\end{array}$ & 0.391 & 4.762 & 0.000 \\
\hline
\end{tabular}

Nilai koefisien jalur masing masing variabel dapat dilihat dalam Tabel 16. Berdasarkan tabel 16 di atas dapat diketahui pengaruh langsung Proses Reviu terhadap Kualitas LKPD memiliki nilai tstatistik sebesar 4,185 >1,96 dan $\rho$-value sebesar $0,000<0,05$ yang menunjukkan pengaruh tersebut signifikan, dan nilai koefisien jalur sebesar 0,303 menunjukkan bahwa variabel Proses Reviu berpengaruh positif terhadap variabel Kualitas LKPDsehingga dapat diartikan bahwa hipotesis pertama diterima.

Pengujian hipotesis kedua bahwa pemahaman standar akuntansi pemerintahan oleh APIP akan memoderasi pengaruh proses reviu terhadap kualitas laporan keuangan pemerintah daerah maka dapat dilihat dalam tabel 4.15 diatas bahwa nilai koefisien jalur efek moderasi sebesar 0,199 lebih kecil dari nilai koefisien jalur pengaruh proses reviu terhadap kualitas LKPD yang sebesar 0,303. Nilai t-statistik efek moderasi sebesar 3,246 lebih kecil dari nilai t-statistik pengaruh proses reviu terhadap kualitas LKPD yang sebesar 4,185. Sehingga dapat diartikan bahwa pengaruh moderasi variabel pemahaman SAP ternyata tidak lebih baik dari hubungan langsung jalur pengaruh proses reviu terhadap kualitas LKPD, sehingga hipotesis kedua ditolak.

\section{E. SIMPULAN DAN SARAN}

\section{Kesimpulan}

Berdasarkan hasil penelitian sebagaimana telah diuraikan dalam bab sebelumnya dapat ditarik beberapa kesimpulan yaitu:

1. Proses reviu yang dilakukan oleh tim reviu Inspektorat Kabupaten/Kota se Provinsi Lampung secara signifikan berpengaruh positif terhadap kualitas laporan keuangan masing masing daerah kabupaten/kota tersebut. Ini dapat dimaknai bahwa semakin baik proses reviu atas Laporan Keuangan Pemerintah Daerah dapat meningkatkan kualitas Laporan Keuangan Pemerintah Daerah.

2. Pemahaman SAP yang dimiliki oleh APIP berpengaruh langsung terhadap kualitas LKPD namun pemahaman SAP tidak memoderasi pengaruh proses reviu terhadap kualitas LKPD.

\section{Keterbatasan} lain yaitu:

Keterbatasan dalam penelitian ini yang mungkin berdampak terhadap hasil penelitian antara

1. Responden yang menjadi objek peneltian ini hanya terbatas pada anggota tim reviu pada inspektorat kabupaten/kota di Provinsi Lampung saja.

2. Hanya terdapat dua variabel independen dalam penelitian ini yaitu Pemahaman SAP dan Proses Reviu yang berpengaruh terhadap variabel dependen yaitu Kualitas LKPD. 
3. Koefisien determinasi $\left(\mathrm{R}^{2}\right)$ dalam penelitian ini yang hanya sebesar $35 \%$ sedangkan $65 \%$ dijelaskan oleh variabel lain diluar penelitian ini. Ini menunjukkan kemungkinan masih banyak faktor lain di luar penelitian ini yang dapat mempengaruhi kualitas LKPD.

4. Penelitian ini menggunakan indikator variabel dari peneltian terdahulu, dari 29 indikator harus ada 6 indikator yang dihilangkan dalam analisis data. Diharapkan penelitian selanjutnya dapat menggunakan indikator lain yang lebih baik dari penelitian ini.

5. Penelitian ini baru melihat kesesuaian prosedur reviu yang dilakukan oleh tim reviu dengan pedoman pelaksanaan reviu, belum mengevaluasi kualitas reviu yang dilakukan tim reviu.

6. Pada saat penelitian ini dilakukan pedoman pelaksanaan reviu atas laporan keuangan pemerintah daerah yaitu Peraturan Menteri Dalam Negeri Nomor 4 Tahun 2008 belum disesuaikan dengan Peraturan Pemerintah Nomor 71 Tahun 2010 tentang Standar Akuntansi Pemerintahan. Kementerian Dalam Negeri sampai saat penelitian selesai dilakukan belum mengeluarkan pedoman pelaksanaan reviu yang baru yang sesuai dengan Peraturan Pemerintah Nomor 71 Tahun 2010 tentang Standar Akuntansi Pemerintahan.

7. Peneliti belum mengobservasi proses reviu saat tahapan pelaksanaan reviu secara langsung, observasi dilakukan pasca pelaksanaan reviu.

8. Kuesioner yang digunakan untuk menggali persepsi responden atas pelaksanaan reviu diadopsi dari penelitian terdahulu yang baru menilai kesesuaian prosedur pelaksanaan reviu dengan pedoman pelaksanaan reviu namun belum sampai menguji/mengevaluasi kualitas pelaksanaan reviu.

\section{REFERENSI}

Badan Pengawasan Keuangan dan Pembangunan (BPKP). 2008. Kode Etik dan Standar Audit.

Chin, W. W. 1998b. The Partial Least Squares Approach to Structural Equation Modeling, in Modern Methods for Business Research, G. A.Marcoulides (ed.), Mahwah, NJ: Erlbaum, pp. 295358.

Ghozali, Imam. 2014. Structural Equation Model Metode Alternatif dengan Partial Least Squares (PLS). Edisi 4. Semarang: Badan Penerbit Universitas Diponegoro.

Humiang, Greaty Prilen., Saerang, David P E., \& Karamoy, Herman. 2015. Analisis Kesiapan Pemerintah Daerah Dalam Menerapkan Standar Akuntansi Pemerintahan Berbasis Akrual dan Dampaknya Terhadap Sumber Daya Manusia Pada Pemerintah Kota Bitung. Jurnal Riset Akuntansi dan Auditing Vol. 6 No. 1, Juni.

IHPS (Ikhtisar Hasil Pemeriksaan Semester) I. 2016. Badan Pemeriksa Keuangan Republik Indonesia.

Jogiyanto. 2008. Metodologi Peneltian Sistem Informasi. Yogyakarta. Penerbit Andi.

Muhaimin., \& Yunitarini, Siti. 2009. Pengaruh Pemahaman Aparat dan Kesiapan Lembaga terhadap Kesuksesan Implementasi Sistem Akuntansi Pemerintahan di Pemerintah Daerah Kota dan Kabupaten se-Eks Karesidenan Pekalongan. Jurnal Kajian Akuntansi, Agustus. Hal; 100 116.

Republik Indonesia, 2003, Undang-undang Republik Indonesia nomor 17 Tahun 2003 tentang Keuangan Negara.

Republik Indonesia, 2004, Undang-undang Republik Indonesia nomor 15 Tahun 2004 tentang Pemeriksaan Pengelolaan dan Tanggng Jawab Keuangan Negara . 
Republik Indonesia, 2006, Peraturan Pemerintah Republik Indonesia nomor 8 Tahun 2006 tentang Pelaporan Keuangan dan Kinerja Instansi Pemerintah.

Republik Indonesia, 2008, Peraturan Menteri Dalam Negeri nomor 4 Tahun 2008 tentang Pedoman Pelaksanaan Reviu Atas Laporan Keuangan Pemerintah Daerah.

Setyaningsih, Tatik. 2013. Studi Eksplorasi Tingkat Pemahaman Aparatur Pemerintah dan Anggota DPRD Terhadap Standar Akuntansi Berbasis Akrual (Kasus di Pemerintah Kota Surakarta). Simposiun Nasional Akuntansi XVI.

Sugiyono. 2014. Metode Penelitian Kuantitatif dan Kualitatif dan RD, Bandung: Penerbit Alfabeta.

Windarsih, Dwi. 2015. Hubungan Antara Reviu Laporan Keuangan Dengan Temuan Pemeriksaan BPK Pada Pemerintah Kabupaten/Kota se-DIY. (Tesis) Fakultas Ekonomika dan Bisnis Universitas Gadjah Mada. 